\title{
Catholic Poles in the USSR during the Second World War*
}

\author{
JÓZEF GULA
}

The first of September 1939 was a tragic day in the history of Poland: the German army invaded the country from the west. Within a short time, on 17 September, a second invasion took place: in close cooperation with the Germans, the Soviet army invaded from the east, and some $1,500,000$ Poles were subsequently deported to prisons, concentration camps and exile in the Soviet Union.

In the Soviet Union, all forms of religious life were systematically suppressed. Those who openly professed their religious faith qualified for prison and death. Thus the Poles, the vast majority of whom were religious believers, were an endangered species in Russia. Ironically, it was the German invasion of Russia in June 1941 which helped to relax for a year the deadly yoke of this oppression. At the time of this invasion, over 100,000 of the exiled Poles enjoyed, one may say, a degree of religious freedom. Their camps became oases of religious life unique in the country; and they are the subject of this article.

\section{Introduction: the Historical Context}

The written history of Poland from the tenth century onwards shows a strong link between church and state. The adoption of Christianity from Rome is seen now not only as a result of the zealous work of missionaries but also as a calculated political decision by the reigning prince. By accepting the influence of Rome, the Polish Kingdom was 'westernised' and under the leadership of the Piast family incorporated into a Christian Europe. A peculiar feature of the Kingdom of Poland was that kings or queens had little chance of absolute power; indeed, they were sometimes elected by the szlachta, the Polish upper class. This state of affairs was also reflected in church-state relations. The church, though cooperating with the state, became to a large extent independent. This position gave the leaders of the church an opportunity for intermediary action and allowed them to point out shortcomings in the nation's life. The lack of absolutist central power and relative freedom in the kingdom helped to create a multinational state, where many nationalities could develop their cultural and religious life. This feature of Polish life attracted, for example, Scottish Protestants persecuted for their faith in their own country. Catholic Poland offered them refuge and the right to worship according to their traditions. In Leszno Wielkopolskie, for example, Scottish traditions are evident even today. This was also

*This article is based on a doctoral thesis The Roman Catholic Church in the History of the Polish Exiled Community in Great Britain (1939-1950), published by the School of Slavonic and East European Studies, London University, in October 1993. 
the reason for the existence of the largest Jewish community in Europe. Catholic Poland was a haven for Jews persecuted in other European countries.

At the end of the eighteenth century the Kingdom of Poland existed in a diverse and hostile world. The lack of power of the Polish monarchy was apparent. Anarchic freedom inside the country, in an age of rising absolutism, brought the nation to the point of tragedy. Poland was not prepared for international conflict on a large scale and Polish diplomacy was not able to defend the country against its enemies. The lack of a strong central authority and of a large and disciplined army prepared to defend the country, corruption among influential families and clans, the selfishness of the szlachta together with social neglect and oppression of the lower classes meant that the safety of the Polish Kingdom was not assured. There were, it is true, individuals calling for urgent reforms in the social life of the country and the first signs of change were becoming apparent. Yet these voices were too weak to influence the ruling classes and strengthen the disintegrating country. All efforts came too late and could not stop the political death of the Polish Kingdom which was partitioned among the three powerful neighbouring states, Russia, Prussia and Austria. They were motivated not only by the desire for territory. The concept of personal freedom cultivated in Poland and the degree of contempt shown for central power - king, tsar or kaiser - might spread to their own countries, causing major problems. The French revolution (1789) was a grim warning and it was clear that Poland had to die. The process started with the First Partition (1772) and the death blow came with the Third Partition (1794). The Polish Kingdom vanished from the map of Europe.

Thus at the end of the eighteenth century a rather unusual country disappeared: though calling itself the Polish Kingdom, it was multinational; though proudly calling itself Catholic it experienced no religious wars between existing denominations; though fervently Catholic, it was also a refuge for Jews persecuted in other European countries.

Little hope lay in help from other countries as none of the European powers could expect to benefit from open involvement in a conflict concerning Poland. Certain radical secret societies, mostly French, did, however, become an inspiration for those Poles preparing an armed uprising in their country. Of course, the uprisings had no chance of success, yet the losses, death, imprisonment and exile did fulfil a very useful function by awakening the spirit of the nation to work and fight for a better future for a free and independent Poland.

The awakening of national pride and spirit became evident in the nineteenth century in the works of poets, writers, historians, musicians and painters, who became the educators of the generations born in an enslaved country. They produced profound analyses of the historical events which had led to the invasion and partition of their country by neighbouring powers. These events were proof of the deceitful intentions of these powers, but also proof of Polish naivety, lack of care for the common good, corruption and social injustice. The Partitions were seen as a punishment from God. The punished nation had to suffer, but through this suffering it would be cleansed, rising from the ashes to a new and better existence. This process miraculously occurred in all the politically separated parts of the old Polish Kingdom, assisted by two influential institutions: the Catholic Church and the Polish family.

The Catholic Church gave the Poles a distinctive character, different from the Germans and the Russians. The Prussian Germans were Lutheran and the Russians were Orthodox. Both denominations, at that time, were instruments of absolute power for the kaiser and tsar, and hostile towards Catholicism. The administration of the Catholic Church embraced the old Polish territories and so unified the divided Polish 
Kingdom. The old places of pilgrimage were venerated and visited without regard for the tripartite division, and there the pilgrims were as one nation. They prayed together and discussed common problems, encouraging each other to be loyal to God and the nation. The often misinterpreted saying 'Polak-katolik' - to be a Pole is to be a Catholic - was at that time well understood.

This Catholic nation, semper fidelis, did, however, sometimes demonstrate a very peculiar attitude towards the pope. The western secret societies were mostly of radical and Masonic character and they supported - for their own purposes, of course - the Polish patriots in their fight for freedom. Yet the pope ruled out membership of Masonic lodges for Catholics. Pope Gregory XVI did not condemn the peacetime invasion of Poland as a political crime: he sent the tsar a friendly message and encouraged the Poles to show loyalty to the invader. As rulers of the Vatican State, the nineteenth-century popes feared instability and revolution. They were also closely linked by diplomatic ties with various political powers, who hoped for help and understanding of their needs. These political powers had their embassies in the Vatican, and they supplied the Vatican with information, which more often than not was biased in their own favour. Poland, which did not exist in the political sense, was deprived of the same opportunities. The bishops' visits to the Vatican had no political weight, and were of pastoral significance only. This state of affairs placed the Vatican in a most unfavourable light from the point of view of the Poles. It appeared that the Vatican was being forced by the political situation to make pronouncements which were most embarrassing to a Catholic nation, that it was misinformed about the conditions in the occupied country, and that it misinterpreted the role of Polish secret societies, which were not bent on revolution per se, but working for the freedom of their country. Orders from Rome were therefore respectfully ignored by many Catholics. As some of the pope's decisions were never formally published in many parts of the country, they were in any case not legally binding. Within the Polish lands, the Catholic Church was at one with the nation in all its attempts to regain its lost freedom. Catholic priests worked together with freedom fighters, were arrested, executed, imprisoned and exiled to Siberia. Members of the Masonic lodges were buried in Catholic churches, sometimes with great pomp and ceremony. Crowds would congregate in the churches and pray whenever events of significance or a national tragedy occurred.

The other influential Polish institution at this time was the family, which remained independent of outside political changes. The German or Russian language may have had to be used in the street or at school, but in the family everybody spoke Polish. On the streets or at school children saw monuments or portraits of foreign kings; in the family home, however, they would see a crucifix and portraits of national heroes. The family was a school for Polish history, Polish literature and, of course, religion. National anniversaries and religious festivals were celebrated, accompanied by music and song, and were as milestones measuring the passing of time. Trusting in God and in his mercy and justice, the Poles maintained a positive attitude and believed that their nation would see better times.

The political situation after the First World War and the expectations of the divided nation were in harmony when in 1918 Poland was raised from the ashes. The gigantic task began of uniting a nation torn apart for almost 150 years. There existed three systems of administration, managed mostly in the Russian and German languages. Three different currencies were in use, there were three organised armies and three railway systems, and the schools had three differing systems of education. Corruption and distrust towards the administration representing the occupying powers were endemic. Some Poles who had been working for years in government offices or were 
members of the army and had been educated in Russian or German schools hardly spoke Polish. The Catholic Church, the most important force uniting the nation in the past, had also suffered because of different traditions in the three political and cultural milieus.

These conditions, combined with the danger from bolshevik Russia, gave no time for any delay in the work of unification. In the first issue of the Komintern paper in 1919, Zinov'yev proclaimed that in a year the whole of Europe would be under communist rule. There was only one road to the conquest of Europe and that was through Poland, where the bolshevik forces did not expect much resistance from the Poles. The Polish army, equipped with a variety of armaments, differing in styles of schooling and combat training, with poor supply lines and transport, was apparently no match for the highly motivated and well-prepared bolshevik forces. In 1920 they crossed the frontiers of Poland, and swiftly destroying the hastily prepared defences advanced towards Warsaw, the heart of the country. There a surprise awaited them. In an extraordinarily well-planned counterattack, the Poles won the decisive battle of the Vistula and saw the bolshevik army decimated and fleeing: 15 August 1920 remained in Polish history as the day of the 'Miracle of the Vistula'. Without this miracle, the history of Europe could have been similar to that of the Soviet Union. Poland stopped the spread of communism in Europe for 20 years.

Free and independent, the country survived many internal problems, political, economic and social. The years after the war saw hyperinflation and unemployment throughout the world, and Poland had its share of misery; yet the process of unification of the country progressed apace and in this the family, the church and the schools worked together.

On 1 September 1939 the Germans invaded Poland. They struck using their best army units, a large number of well-equipped armoured brigades and a powerful air force. It rapidly became obvious that the Polish forces did not have the capability of maintaining resistance for more than a short time. However, they did not surrender. For some of the Polish army units, about 100,000 men, the fierce encounters with the enemy were interrupted on 18 September 1939 by an order from Marshal Smigly-Rydz to retreat to friendly neighbouring countries. They crossed over to Romania, Hungary, Lithuania or Latvia and from there, in small groups, together with a number of civilians, made their way to France or to Syria, then under French rule. Certain units of the Polish navy managed to reach British harbours. To the soldiers the reason for this order was clear: they were not escaping, but merely moving to another area in order to fight on after a short lull in the battle. Even so, the moment of departure was painful. General Dembiński was seen to kneel at the side of the road and kiss the ground on the Polish side of the border before giving his men the order to march into Hungary. Some Polish units, trusting in the promises of safe passage, went over to Romania and Hungary with their armaments. The Tenth Cavalry Brigade crossed over to Hungary with all its artillery together with a quantity of German armour, the spoils of a victorious battle. In a short time, however, they had to surrender their arms and were sent to internment camps. The Polish government was also interned, together with a great number of Polish civilians who were ready to join a reorganised Polish army abroad.

The Poles felt hopelessly defeated. They accused the government and the higher ranks in the army of failing to prepare adequately for war. They also blamed the Allies, particularly Great Britain, for failing to respond with concrete military aid. However, they also felt a responsibility for the future of the country they had left. Their homes, families and friends were ever in their minds. Some were haunted by feelings of shame, 
hearing of their friends being killed and others fighting, while they themselves, although for the best possible reasons, were in the safety of Romania or Hungary. Shocked by personal tragic experiences, the Poles lost touch with their friends. They suffered great loneliness and, immersed in their own suffering, did not concern themselves with others.

It was fortunate that in the first months of their lives abroad the exiles were supported by the Red Cross and various American, British and Hungaro-Polish charitable committees, together with a well-organised Polish Committee in Romania. The Polish Embassy in Budapest, open up to the end of 1940, was able to help those in need by paying them modest benefits. In Hungary, the Catholic chaplains, under the charge of Father Witosławski, organised a Polish Catholic Centre to take care of the pastoral needs of the exiles.

For some, the experience was overwhelming. The wojewoda of Lwów, Dr Bilyk, overwhelmed by mounting problems, committed suicide in a moment of deep depression. In such desperate circumstances chaplains had an important task to perform. Religion was the only stabilising element in people's lives. Mass celebrated by a Catholic chaplain was a memorable occasion uniting everybody in prayer and bringing some peace of mind. In the Pauline Church on St Gellert's Hill in Budapest there was an altar to Our Lady of Częstochowa which helped those in grief to unite spiritually with their families in Poland. Marshal Smigly-Rydz was often seen to pray in front of this altar. Later he was to remind his friends of the masses celebrated in this Hungarian chapel, the congregation spilling over into the park around it, as a time of heartfelt prayer.

The priests accompanying the army units were the backbone of the pastoral structure which cared for the exiles in Hungary and Romania. The Polish Catholic Mission offered pastoral help to the needy. Some of the priests worked in close cooperation with the Polish leaders Marshal Smigly-Rydz and General Wladysław Sikorski. Father Zapala, an army chaplain, was the trusted friend and companion of Marshal Smigly-Rydz in Romania and Hungary and on the return journey to Poland. Father Miodoński was a man closely connected with General Sikorski and the Polish army in France. Apart from his priestly duties he personally supervised and selected all those volunteering to serve in France.

In spite of Romanian guarantees of safe passage to France, the Polish government was interned by the Romanian authorities. This resulted in a decision by the interned Polish President Ignacy Mościcki, within his special constitutional powers, to designate a successor, W. Raczkiewicz, who would perform all presidential duties without hindrance. On 30 September 1939 the new head of state President Raczkiewicz took the oath of office in the Polish Embassy in Paris and formed the Polish Government in Exile. On the same day General Wladysław Sikorski was appointed Prime Minister, and on 7 November 1939 he became Commander-in-Chief of the Polish armed forces. Poles residing in France, together with newly arrived exiles, were recruited by General Sikorski into an 80,000-strong Polish army made up of 7,661 officers and 74,600 enlisted men, stationed mainly in France. Former army chaplains and clergy called up by the war mobilisation order helped to staff the newly organised units with the requisite number of chaplains.

The Polish army in France fought in 1940 in Norway and against the Germans invading France. France surrendered in June 1940. The Poles did not. In 1940, after the fall of France, almost 24,000 Polish servicemen were transferred to Great Britain, often in extremely dangerous circumstances. With all due respect to its heroic efforts, a Polish army of this size was not a force capable of influencing the future of the war. 
The British Foreign Office saw it as important in maintaining morale in Poland rather than as a practical strategic force. The Polish command, however, had quite different plans for this army, regarding it as a nucleus which would grow and develop.

Common soldiers are the backbone of an army, but in this case they were in short supply. Continental Europe was now closed, so new recruits from there were out of the question. Great Britain had a population of no more than 3,000 Polish émigrés. The Polish high command was therefore obliged to turn to countries with a sizeable Polish émigré population, which were still free and open to visitors and which above all were not hostile to recruitment for the Polish army. The United States of America and Canada were seen as a promised land by General Sikorski and his aides. They hoped for 200,000 Polish volunteers. Sikorski's visit to Canada and the United States was not easy to plan. Due to imminent danger of a German invasion he was obliged, as Commander-in-Chief of the Polish forces, to stay with the army. Moreover, the intense activity of the German navy and air force made his trip to America extremely risky. These considerations and the necessary diplomatic preparations meant that the visit took two months to organise. General Sikorski left Britain on 23 March 1941 on the British warship Revenge and arrived in Halifax (Canada) on 1 April. His diplomatic talks with the Canadian government were finalised by the signing of a treaty of cooperation. Talks with President Roosevelt, on the other hand, were considerably cooler. As a neutral country, the United States had made open recruitment to the Polish army illegal. All that was permissible was private recruitment in Polish communities, all recruits being subsequently sent off to army camps in Canada.

On 12 May 1941 General Sikorski arrived back in London. Recruitment in the United States and Canada had added a mere 722 soldiers to the Polish army. However, new intelligence about concentrations of the German army on the borders with the Soviet Union gave the general no time to worry about the poor results of his American visit. On 22 June 1941 the German army attacked the Soviet Union.

The German-Soviet war was welcomed by the British government as a positive and helpful development. The vast expanse of the Soviet Union, with its large population, engaged many divisions of the attacking German army, using up huge amounts of equipment. As a result, pressure on the western front was bound to lessen. After initial military success, the Germans encountered strong resistance from the Soviet people and the unusually severe Russian climate was also a considerable help to the Allies. There were indeed many reasons for welcoming the new war.

The Poles saw the new situation in a different light. The Soviet Union had been an aggressor just as much as Nazi Germany. On 17 September 1939 the Soviet army had occupied Polish territory while the Polish army was defending the country against the Germans. Attacked from both east and west, the Poles had no chance of defending themselves. The 300,000-strong Polish army in the occupied territories was imprisoned in concentration camps. One and a half million Polish civilians, men, women and children, were exiled from their country in subhuman conditions and were settled in penal colonies in Siberia. All these acts were considered criminal not only by the Poles but also by international law. The new danger threatening the Soviet Union might now lead to positive changes. The Soviet forces could now be compelled to withdraw from Poland, release the exiled cvilians and allow the imprisoned Polish army to take part in the fight for the freedom of Poland, side by side with the Soviet forces. General Sikorski was a man of great political intuition. Unlike many politicians, he had anticipated the changes and was ready to react instantly to the new situation.

On 23 June 1941, just one day after the beginning of the German-Soviet conflict, General Sikorski explained the situation in a special broadcast transmitted to Poland. 
The Soviet authorities reacted positively to his words, and on 4 July contacted an intermediary, Anthony Eden, the British Foreign Minister. Polish-Soviet talks began the next day. The problem of the interned army and its use in the fight against the Germans was quite easy to solve. The right of Poles to be returned to their country was acknowledged but war conditions gave the Soviet authorities a pretext to shelve the details of this task. The third problem was the most difficult - the Polish government expected a return to prewar borders with the Soviet Union. The Soviet authorities opposed this categorically. As a result the talks, which lasted until $30 \mathrm{July}$, achieved nothing.

On 30 July, the Polish Prime Minister Sikorski, under pressure from Churchill and the British government and in spite of the misgivings of President Raczkiewicz and certain Polish political parties, signed an agreement with the Soviet authorities. The main points were: that the Soviet-German treaty and territorial changes in Poland from 1939 were abrogated; that diplomatic relations were resumed and ambassadors exchanged; that mutual help in the fight against Hitler's Germany was promised; and that Soviet agreement on the formation of a Polish army in the USSR was given. This was the maximum that the Polish government was able to achieve at such a decisive moment.

On 12 August 1941, the Soviet government announced an amnesty for interned and expatriate Poles on Soviet territory. Sikorski's agreement was welcomed with great joy by all Poles imprisoned in the Soviet Union.

\section{Exiled to an 'Inhuman Land'}

Polish citizens were of many nationalities. Polish passports made a clear differentiation between nationality and citizenship. Poles, Jews, Ukrainians, Russians, Belorussians, Lithuanians, Czechs and others living in Poland were considered to be Polish citizens without having to change their nationality, and had the right to be treated in the same way as Poles. Members of these nationalities were deported to the Soviet Union together with ethnic Poles; so the word 'Poles' in the context of those exiled to Russia also includes these minorities.

Polish servicemen and civilians had heard from the experience of others how insecure, dangerous and difficult life was in the USSR before the outbreak of war. However, their own experiences after 17 September 1939 surpassed both the accounts of others and whatever they might have imagined: terror, fear, arrests, rape, robberies, beatings, torture, executions without court orders, overflowing prisons, concentration camps, incitement to hatred among ethnic minorities who had for centuries been living together. ${ }^{1}$ Violations of human rights sometimes occur in wartime when social and moral discipline disintegrates and primitive instincts take over. In this case, however, the violations had been meticulously planned. Lists of suspected people, professions, institutions and nationalities had been well prepared in advance. Locations of places of imprisonment and concentration camps had been designated. Thousands of cattle wagons and trains had been commandeered, and their journeys harmonised with normal train services.

In many ways, the work of the Soviet NKVD in eastern Poland proved far more destructive than that of the Gestapo at this stage. Having longer experience of political terror than their German counterparts, the Soviets had no need for wasteful experimentation. Their expertise had been refined, and their personnel thoroughly trained and replenished in the recent Purges; 
and they went into action with speed. As in the German Zone, the population was screened, classified, and segregated. But in this case, all unfavourable elements were physically removed from the scene as soon as they were identified. An NKVD decree, issued in Wilno (Vilnius) in 1940 lists the categories of people subject to deportation:

1 Members of the Russian pre-revolutionary parties - Mensheviks, followers of Trotsky, and anarchists;

2 Members of contemporary (national) political parties, including students belonging to student organizations;

3 Members of the state police, gendarmerie, and prison staffs;

4 Officers of the former Tsarist Army and of other anti-Bolshevik armies of the period 1918-1921;

5 Officers and military judges of the contemporary Polish and Lithuanian armies;

6 Volunteers of all other armies other than the Bolshevik;

7 Persons removed from the Communist Party;

8 Refugees, political émigrés, and contraband runners;

9 Citizens of foreign states, representatives of foreign firms etc.;

10 Persons who have travelled abroad. Persons who are in contact with representatives of foreign states. Persons who are esperantists or philatelists;

11 Officials of the Lithuanian Ministries;

12 The staff of the Red Cross;

13 Persons active in parishes; clergymen, secretaries, and active members of religious communities;

14 Aristocrats, landowners, wealthy merchants, bankers, industrialists, hotel and restaurant proprietors. ${ }^{2}$

The exile of hundreds of thousands of people from the eastern part of Poland organised by the Soviet authorities after 1939 had, in the view of W. PobógMalinowski and others, one purpose, namely genocide.

In the spring of 1940 a large-scale scheme of deportation of millions of Polish citizens, mainly native Poles from the eastern parts of Poland, was put into operation. The main aim of the plan was to destroy 'dangerous and antisoviet elements' in the Polish areas annexed by the Soviet Union. Proof of the planned total destruction of the deported Polish population lay in the conditions in which the deportations were conducted and in the prisons and concentration camps prepared for deportees as well as in the dispatching of hundreds of thousands of civilians to Northern Russia, Siberia and Central Asia where the climate and living conditions were intolerable for any human being. ${ }^{3}$.

Documents which were secret at the time and the memoirs of surviving former deportees, which have since been collected and published, disclose the horrifying methods and purpose of these deportations. ${ }^{4}$ About half of all the exiles died within one year. Many of those who survived and were released from imprisonment were sick in mind and body.

On 26 April 1943, in his report to General Sikorski, General Anders spoke of some 500,000 Polish soldiers imprisoned in the Soviet Union. ${ }^{5}$ There were about 150 concentration camps designated for the Polish army, including 99 built in Soviet- 
occupied areas of Poland. ${ }^{6}$ They housed about 100,000 officers and soldiers. Conditions were grim - no washing facilities, hunger, hard labour, no medical care and a huge mortality rate.

The civilians were deported in four groups. The first deportation was organised on 10 February 1940, when 220,000 men, women and children were transferred to the northern part of European Russia. The second deportation of about 320,000, mainly women and children, started on 13 April 1940. They were taken to Asiatic Russia, mainly to Kazakhstan. The third was in June and July 1940 and involved mostly refugees from western and central parts of Poland. They were moved to the north of the USSR, around Arkhangel'sk, Sverdlovsk and Novosibirsk, to the Bashkir and Mari republics and to Krasnoyarsky krai. The fourth deportation was in June 1941. About 100,000 Poles, mainly from the Wilno area, were expelled from their homes and exiled by train to various parts of the USSR. ${ }^{7}$

They had all been processed by the NKVD and sentenced either to lagier (concentration camps), to hard labour, or to penal exile. The vast majority were convicted for no known offence, but simply because the Polish nation was seen as the inveterate enemy of its Russian masters. The conditions in those trains defy coherent language. The passengers had been told to pack emergency rations for one month, but to take a minimum of personal belongings. They were packed in a standing position in sealed, windowless and unheated cattle-wagons, for a winter journey of three, four, five or even six thousand miles. Their only view of the outside world was through a small opening under the roof which could be used for passing out excreta and corpses. Instances of derangement, frostbite, starvation, infanticide, even cannibalism occurred. Those who survived the trains often faced further journeys in the holds of riverboats, or on the backs of open lorries, to the farthest recesses of the Soviet wilderness. ${ }^{8}$

In the 20 months of Soviet occupation about $1,700,000$ Polish citizens were deported by the NKVD to the Soviet Union. They included some 560,000 women, 138,000 children and 150,000 elderly persons. ${ }^{9}$

The primitive biological Darwinism essential to Marxism helped in furthering plans for the destruction of many millions of people in the Soviet Union. The same plans were put into effect in the context of the arrest and deportation of the Poles. They were to be destroyed physically, deprived of food and sleep, bitten by insects and crowded into cattlewagons without any sanitary facilities. They were to be destroyed psychologically, uprooted by force from the country of their birth, removed from their own culture, their way of life, their churches, schools and homes, friends and relatives. They were deprived of all the small yet necessary articles essential to normal everyday life, such as books, pens, soap, money, clean shirts, socks, sheets. Personal possessions were limited to a pack of dry food and some clothes. They were to be destroyed morally. Men with social positions soon became nobodies. They were stripped of everything which made them independent and self-supporting. A sense of human dignity, so important to man's well-being, vanished in an almost animal fight for survival. The whole structure of moral life was destroyed: concepts of justice, charity, mercy, love, reward and punishment were no longer valid.

By the time that the Amnesty was granted in 1941 (for crimes that had not been committed), almost half of the one-and-a-half million Poles deported in the previous years were already dead.... There is little doubt that if the 
Nazi-Soviet Pact had lasted much longer, the goal of the two participants with regard to Poland would have been achieved. By 1941, the Nazi extermination machine was moving into top gear. The Soviets needed no encouragement. Isolated from all outside help, the Polish nation could not conceivably have survived in any recognizable form. Fortunately for them, the vagaries of war turned in their favour. The Poles were saved by the German attack on Russia. Although four long years of horror remained, the Germans were to prove incapable of annihilating Poland single-handed. The Soviets, who for two years had acted as Hitler's chief accomplices, turned for Polish assistance. The Poles were spared total annihilation. ${ }^{10}$

\section{Self-defence}

The order for deportation was sudden and gave very little time for preparation. In the short time allocated for collecting indispensable articles, the prisoners nevertheless took care to collect, apart from clothing and food, certain small items which they instinctively felt to be essential in preserving their identity and human dignity. From the wall of her school one teacher took a small cross and packed it with her clothing. " The cross accompanied her through all her war experiences. Others also took small crosses, prayer books, pictures of Our Lady Queen of Poland, the Polish coat-of-arms - all those things which reminded them of their past identity. Religion, in the sense of an intimate faith, was the only part of their life which was inaccessible to their persecutors. Religious symbols like crosses, medallions and pictures were for them a constant reminder of this freedom and a sign of hope for a better future. These symbols had the power of mobilising their spiritual strength. They were also intermediaries, as it were, between close friends and family members, and as such they were deeply respected and venerated by the deportees.

Prayer books were exceptionally important as prayer was the main vehicle by which the deportees expressed their religious faith. For many starving people the spiritual power conveyed through prayer meant more than bread. ${ }^{12}$ In that it linked the believer with his Creator, prayer had a profound psychological effect. It provided a means of escape from the horrifying conditions of everyday life with its uncertainties, cruelties and corruption. ${ }^{13}$ It had the power of steering the human mind towards spiritual goodness and beauty. The habit of prayer was also a simple way of assessing a human being. A man who prays must be a good man. ${ }^{14}$ The exiles needed this certainty in the 'Inhuman Land', as they called it.

The Polish language, traditions and songs were of great significance to the exiles. So was the presence in their midst of their spiritual leaders. Catholic priests, Orthodox and Protestant clergymen and Jewish rabbis were among those deported, as were members of the 'intelligentsia' and active professional people. The presence of such people was providential for the survival of a great number of exiles. The sheer number of deportees gave rise to the feeling that the whole community, the whole nation, was under attack: and this in turn mitigated the sense of individual isolation. The conditions of travel and imprisonment brought together people of different levels of education and various professions. Sharing their experiences with others and discussing burning problems was a great comfort and a source of moral strength for all of them.

When the deportations began, it often happened that priests tried to join their despairing parishioners and to go voluntarily with them into exile. The NKVD, 
however, often removed them by force from the departing groups. ${ }^{15}$ Shortly afterwards they would also be arrested and condemned to prison, death or exile. Subsequent clandestine activity by these priests would be one way in which the church could extend its influence. According to Fr Cieński, this was a time when Polish priests evolved a new kind of pastoral work among the exiles, which they subsequently practised throughout the whole of the Second World War. ${ }^{16}$

Pastoral duties were first performed unofficially and in secret in prisons and concentration camps. Facing long prison sentences or even death, imprisoned Catholics would ask priests to hear their confession. The priests in turn organised religious meditations in prison cells and religious lectures and discussions with their fellow prisoners and guards, and they also prepared certain non-Catholics for conversion. ${ }^{17}$

The brutality of everyday life endangered the type of Catholicism practised by many Poles in prewar Poland, which was to a large extent populist, based on the traditions of small towns and villages, emotional and sentimental, combined with a widespread Marian devotion. This age-old traditional Catholicism often generated 'cradle' Catholics who were not used to examining the content of their faith. In the life of exiled Poles there was no place for such sentimentality. The 'cradle' Catholics experienced the bitter truth that a man confessing his religious faith must be prepared for persecution and perhaps martyrdom. The loss of familiar and well-regulated patterns of work and devotions destroyed the religious and moral life of some Poles. Some were easily subdued, frightened and perhaps even blackmailed by the communists. In a short time, some became collaborators and even traitors, used by the NKVD to spy on and control the community. They were feared and despised by everybody. Fr Cieński remembers well the atmosphere of fear and distrust they engendered. ${ }^{18}$ The consequences of their activity were perilous. For example, a certain priest working in secret was identified by an old friend and organist and was arrested and condemned to a concentration camp as a direct result of the 'friend's' report to the NKVD. ${ }^{19}$

In general, however, the clash between the religious convictions of the Poles and the communism of their persecutors did not destroy the faith of the exiles. On the contrary, it seems to have given rise to considerable changes in their attitude to their religion, which grew stronger, became better motivated and came to include a readiness for sacrifice, without losing its Marian devotion and a fervent expression of faith rooted in a simple yet deeply pious folk tradition.

\section{From Death Row to Active Life}

On 30 June 1941, in London, the Soviet Ambassador Maisky and General Sikorski signed the Polish-Soviet agreement, the main subject of which was the Polish question and the formation of a 100,000-strong Polish army in the Soviet Union. Two weeks later, on 14 July, Poland, represented by General Anders, signed a military agreement in Moscow. The formation of a 100,000-strong army apparently caused some concern to the Soviet authorities and the number was brought down to 30,000 ; subsequently it was raised again to 40,000 men.

Father W. Cieński, who seems to have been well-informed and who may well have been briefed by General Anders himself, disclosed the terms on which Anders accepted the duties of Commander-in-Chief of the Polish army. These concerned the character of the army and the position of women's units. The courage of the general, who had been released just ten days before from the Lubyanka prison, was indeed exceptional. In a country which brutally persecuted and executed people professing their religious 
convictions, he demanded the right to organise a Polish army according to Polish traditions and Polish law guaranteed by the Constitution of 1921, and in accordance with the Concordat signed by the Polish government and the Vatican in 1925, which stipulated that Polish chaplains should satisfy the religious needs of the soldiers. Women in the Polish army were to be organised in special support units under the command of women officers. These terms were presented by General Anders to General Panfilov, who accepted Anders' plan; it was later approved by the Soviet government. General Anders wrote later, with obvious satisfaction: 'It was a great accomplishment and a real break into the structure of Soviet life. ${ }^{20} \mathrm{He}$ was a man with a clear vision of a Polish army which would be strong militarily, but which would also care for the spiritual needs of the soldiers. In the first words he addressed to his soldiers on 22 August 1941 he expressed his belief that the Polish army could not exist without God. ${ }^{21}$ Unlike the majority of Poles, General Anders was a Protestant. On 4 September 1941, authorised by the army bishop W. Gawlina in Rome, he promoted Fr Cieński to the duties of Chaplain-in-Chief of the Polish Army in the Soviet Union. Protestant, Orthodox and Jewish chaplaincies were similarly organised. ${ }^{22}$

All this took place over a very short period of time. Fr Cieński left prison on 2 September, and on 4 September presented himself to General Anders, who appointed him to his new post. As Chaplain-in-Chief Fr Cieński celebrated the first Polish mass in the French church in Moscow on 7 September 1941, in the presence of General Anders, the Polish Ambassador in Moscow, officers and soldiers of the new Polish army and local members of the Polish civilian population. ${ }^{23}$

Thus began a period of intensive pastoral work. The chaplaincy did not have any of the essential liturgical requisites and the number of priests released from concentration camps was unknown. The headquarters of the new Polish army was in Buzuluk, in the middle Volga region. When Fr Cieński asked for more precise directions, the answer was that it was situated somewhere between the Urals and the Caspian Sea.

Buzuluk, a small town on the way to nowhere, thus became the 'capital' of the new Polish army, which had to be raised from the ashes. To call Buzuluk a town may be an exaggeration, as it consisted merely of a number of wooden houses and huts prepared for summer army manoeuvres, which in winter were uninhabitable. The deserted and ill-constructed town appeared sad and depressing to the newcomers. However, the Polish flag flying proudly over one of the buildings ${ }^{24}$ lifted their spirits. The General Command of the Polish army was in evidence. 'The sight impressed and moved all Poles arriving from prisons and concentration camps,' wrote General Anders. 'It must be understood that after many years of agony, it was unbelievable to see the Polish flag flying again in Buzuluk. ${ }^{25}$

It took a surprisingly short time for the Poles who had now been released from prisons, concentration camps and places of isolation all over the Soviet Union to fill the huts, tents and mud huts not only in Buzuluk but also in Totskoye and Tatishchevo, a few hundred kilometres away. For many of the travellers, the roads and railway lines became places of death. Exhausted physically, starving, seriously ill, they had no chance of reaching the Buzuluk camp. Their bodies were buried by the roadside and at railway stations. The tragedy of the first deportation was being repeated. ${ }^{26}$ Those who succeeded in reaching the town were emaciated, pale, wearing old, worn-out shoes or simply barefoot and dressed in tattered rags. Fr Cieński, himself released from prison, was shocked by the sight of these pathetic figures. ${ }^{27}$ Yet in these skeletal bodies dwelt a powerful spirit. In spite of their pitiful condition they organised a march-past for General Anders, who for the first time in his life took the salute of barefoot troops. ${ }^{28}$ Feeding the recruits was a problem. The supply of food to Buzuluk was so 
inadequate that they had to be given starvation rations which were even more meagre than in the concentration camps. ${ }^{29}$

By the middle of September 1941, 25,000 men had reported for military service in the Polish army camps. One month later over 36,000 (34,139 privates and 1,965 officers) were registered. According to Polish records, many thousands of officers held in prisons did not arrive in Buzuluk for reasons unknown. When General Anders lodged a complaint, Stalin answered: 'All have been released.30

Many of the new arrivals had no identification papers. Using their imagination, officers working in the General Command had to draw up these essential documents again. The question of identification was particularly difficult for the Chaplain-inChief, Fr Cienski. Many of the men who introduced themselves to him as Catholic priests had no written proof of who they were. There was always the danger that some of these might be impostors trying to get themselves a better position in the army, or even infiltrators from the NKVD. Together with a few other priests, Fr Cieński interviewed and tested every unknown person claiming to be a Catholic priest, asking for details of his ordination and questions on dogma, morals and liturgical problems, and of course testing his knowledge of the Latin language. ${ }^{31}$

\section{Chaplains in the Structure of the Army}

Winter was a time of hardship for the inhabitants of the huts and tents. It began about the end of September, with heavy snowfalls. The wind blew the snow inside the poorly built huts and the temperature plummeted to minus $50^{\circ} \mathrm{C}$. The morale of the army, however, remained rather high. The severity of the climate and lack of food was compensated for by the ingenuity of the soldiers, who skilfully built small hearths and stoked the fires with miraculously acquired wood.

The chaplains did their best to decorate the 'chapel' in Buzuluk: in the past it had been a hut with a large number of crude beds and later a dining room for the soldiers; now it served not only as a chapel but also as a hall for meetings and possibly theatrical shows. The troops needed the chapel after long subjection to atheistic propaganda in isolation camps and prisons. General Anders recalls seeing old soldiers weeping during mass and loudly singing hymns imploring God to grant Poland her freedom. ${ }^{32}$

Celebrating Sunday mass was one of the main duties of the chaplains; and as far as some unit commanders were concerned, it was the only duty of a priest in the army. They did not expect him to perform any other priestly function apart from the occasional funeral, wedding or possibly baptism. Instead they envisaged him at work in libraries and halls, organising educational courses, teaching the history of Poland and encouraging a spirit of patriotism in the army. General Boruta-Spiechowicz, for example, was firm in this view, and General Tokarzewski saw priests as 'instruments of education' of the army, carrying out his direct orders. ${ }^{33}$ The extraordinary process of forming a 'new' army constantly tempted the commanders to create new jobs for the chaplains to do. Fr Cieński appealed to the Commander-in-Chief, General Anders, for a firm ruling. Anders' decision was that the new Polish army and its chaplains would be subject to Polish law, the Concordat of 1925 and the orders of the army bishop dated 20 March 1940. This had been the case in the past and would remain so in the future. The main duty of the chaplain was pastoral work. ${ }^{34}$ Disputes nevertheless continued, with a tendency by officers of all ranks to try to manipulate the activity of the chaplains and reduce their influence. Some officers argued that the talks on moral issues given by priests to the troops were not necessary. Instead, they themselves proposed to deliver educational or patriotic talks. Fr Cieński and the other chaplains 
defended their rights. Recourse to General Anders was inevitable. At a meeting with the commanding officers, General Anders decreed, in no uncertain terms, that the rules given to the chaplains by their bishop, including their right to instruct soldiers and their families on religious and moral subjects, must be accepted by all without question. A vital matter had been settled for both the present and the future. ${ }^{35}$

The legal position of the chaplains in the army was now clear. The Polish army was visibly the army of a Christian nation. A crucifix hung prominently on the wall in every hall, dormitory and refectory. In their units, the chaplains had the rights of parish priests and the duties of pastoral work among the soldiers and their families under the direction of the army bishop. The parish office and the care of books registering baptisms, weddings and burials was also entrusted to them. In all other aspects of their life in the army, they observed army discipline and adhered to the orders of their commanders.

At the beginning of October 1941, a special delivery from London supplied the chaplains with the basic requisites which were indispensable to their work: vestments, chalices, altar wine, missals, books and portable altars. Fr Cieński had to organise the baking of altar bread in the units. The women's units, which included a number of nuns in their ranks, were of great help. The holy oils used in baptisms and for anointing the sick were blessed, at the request of Fr Cieński, by an Orthodox bishop. The unique situation and lack of a Catholic bishop in the vicinity thus encouraged ecumenical cooperation.

In September 1941 Bishop Józef Gawlina instructed the chaplains on the details of their obligations. They were to conduct morning and evening prayers. Protestant, Orthodox and Jewish soldiers had the right to pray according to their own tradition. Sunday services were to be celebrated in denominational groups. Jewish soldiers were to celebrate on Saturday. Days of special significance, like the Trooping of the Colour or Independence Day, were celebrated by soldiers in their units. The Lenten period was observed in the units by two-day retreats for Catholic soldiers, and by confession, communion and fasting on certain days. Jewish soldiers, whose religious traditions required kosher food, were given permission and money to prepare appropriate meals.

The care of the sick in hospitals took up a lot of the chaplains' time. The number of small hospitals was growing. In October 1941, Buzuluk hospital had 83 patients. They needed medical care but also the services of a priest. The priest was of ten the only person ready and able to help in cases of religious and material need at a time when social care was non-existent.

Almost every settlement had to build a cemetery, of ten secured by a solid brick wall. Very soon these cemeteries typically contained between 90 and 1,000 graves. During the period of the existence of the Polish army in the Soviet Union about 10,000 men died in the camps, mostly of malnutrition. Burials were conducted with care and every grave was blessed by a clergyman and decorated with appropriate religious symbols: a cross for Christians, the Star of David for Jews.

As recruits and their families continued to arrive the chaplains had to baptise children, prepare young people for marriage and officiate at wedding ceremonies. They also had to offer counsel on many other issues. There were documents for translation, applications and letters to the authorities in prisons and concentration camps to be written, queries about lost persons and many personal problems to be solved. Chaplains were the most suited to listen to problems and give advice.

The teaching of religion was an unending task. Organising talks in the units was relatively easy. However, with families and orphaned children the situation was more difficult. Chaplains had to travel to various places to contact adults and children and 
instruct them in the faith. In many places they were helped by laypeople and by religious sisters serving in the Auxiliary Women's Corps. There were also large groups of orphans attached to the army. To feed them soldiers had to share their very modest rations, which they did without complaint. The Soviet authorities granted the chaplains the right to work among soldiers and their families, but the pastoral care of families not connected with the army was officially forbidden. In fact, however, chaplains served all who needed help. Spies were active, and chaplains were exposed to severe fines or arrest and imprisonment, so they had to exercise their duties with the utmost care.

It was the chaplains who started to distribute among the Polish exiles very simple information sheets printed on wrapping paper, which slowly became bulletins and, in time, even weekly papers. Professional journalists and writers among the exiles were of great help in this very specialised work.

The Auxiliary Women's Corps, which in the Buzuluk region in November 1941 comprised 940 recruits, ${ }^{36}$ gave valuable support to the chaplains. They helped to teach the children, visited the sick, organised choirs, took care of the chapels and vestments, and worked in the offices.

The cooperation of the women also facilitated the first theatrical performances. While defending their priestly duties as their highest priority, the chaplains understood the significance of cultural events and voluntarily offered their time and talents. Polish shows in the middle of the Soviet Union unified the small communities and raised the spirits of the exiles. In many places the religious and cultural activities of the Poles in the camps attracted the local Russian population. The Russians of course had regular contacts with their own Orthodox priests, but were well aware of the NKVD policy of infiltration of the Orthodox clergy, and did not trust them. At first, the local Russians also suspected the Poles of cooperation with the NKVD, but after a time they gained confidence, and Russians were seen in Polish chapels and halls. They also appreciated the services of Polish doctors and nurses in hospitals, showing their gratitude by helping in their work.

On 11 November, Russian officers unexpectedly attended a celebration marking Polish Independence Day. They were present in the chapel at a solemn mass for Poland and later at a special show commemorating the regaining of freedom in 1918. The part of the show concerning the victorious defence of Poland against the Soviet invasion in 1920, which could have offended the 'eminent guests', was postponed to another day. The guests had the opportunity to discuss and exchange views with the Poles on numerous subjects, and this gave them a good picture of the hopes and morale of the units they visited. Quite possibly their impressions later influenced the decisions of Stalin concerning the future of the Polish army in the Soviet Union.

\section{The Polish Nation in the Soviet Union}

General Sikorski's dream of building up a Polish army had now become a fact. After the depressingly unsuccessful efforts in Canada and the United States and the rather indifferent attitude of old Polish émigrés to the struggles of Poland, the news from the Soviet Union was most refreshing. In the space of a few weeks over 40,000 men from different parts of the Soviet Union had assembled around Buzuluk in a newly formed Polish army, united in the aim of fighting for the freedom of Poland. The difference between these two groups, the émigrés and the Poles in the Soviet Union, was manifest. 'Outside Poland there exist two distinct groups: émigrés and a nation,' said General Sikorski. The 'nation' was in the Soviet Union - the deported Poles. Sikorski centred 
his future plans on the Poles in Russia. Proof of his attitude would be his presence among them, and he planned to visit them.

Bishop Gawlina thought about the Poles in the Soviet Union in similar terms and also planned to go there. ${ }^{37}$ Having set in motion the required formalities with Prime Minister Sikorski and the Soviet authorities, the bishop sent Fr Król, his vicar general, to visit the communities in the care of Polish chaplains. Overcoming various transport problems, Fr Król arrived in Buzuluk on 8 November. On Sunday 11 November he was already preaching to an unexpected crowd of Soviet officials sitting with the Poles in the chapel, and after mass, in the company of other chaplains he discussed with them problems of the future which preoccupied them all at that time. He also announced two other important visits: first that of Prime Minister Sikorski, and later that of Bishop Gawlina.

On 12 November, in spite of heavy snowfalls, Fr Król started visiting the Polish units, accompanied by Fr Cieński. The existence of the Polish army was founded on the Polish-Soviet agreements. To the Polish exiles, however, the Soviet people were enemies, cruel persecutors and cold-blooded killers. Their long isolation in prisons and concentration camps was to some extent healed by meeting fellow countrymen in army camps. Fear of the future, however, was always present. The Soviet people had been treacherous and untrustworthy friends, so a change for the worse was always a possibility. Fr Król's visit and his words assuring the Poles about their unity with the Polish army in Europe and the forthcoming visits of the Polish Prime Minister and of Bishop Gawlina, who were both concerned about them, calmed and diffused old fears and tensions. Reports about the needs of the units reached the General Command and helped to improve neglected areas, speed up deliveries of rugs, bedding and linen and improve morale.

November was thus already an eventful month when another important event occurred: the arrival of a group of officers released from Kozel'sk. The officers brought to Buzuluk a wooden bas-relief of Our Lady of Kozel'sk ${ }^{38}$ which they had venerated in the concentration camp and which symbolised for them the presence of God and the protection of His Providence. The feast of Our Lady on 21 November was marked by a solemn blessing of this icon, which was now called Our Lady of Victory. The soldiers prayed that she would guide them to triumph after so many years of sorrow and defeat.

The officers from Kozel'sk had a concern for moral and religious values. Before long they were proposing to found an organisation called 'Marianum' to combat secularist and atheistic tendencies which they had discovered in the army. This proposal was rejected by Fr Cieński as a potential danger which might lead to division in the units and so harm the army. ${ }^{39}$ It was soon clear that there was indeed opposition to their activity. The official welcome for General Sikorski included a show representing historic and patriotic scenes. Shortly before its performance this show was cancelled by the officer in charge, on suspicion that it originated with the officers from Kozel'sk. This suspicion, as was later proved, was ungrounded. The show was in fact the work of the whole community, of which the said officers were but a small part. Performed later, the show was warmly received and applauded by the audience.

General Sikorski's arrival on 8 December was enthusiastically welcomed. He had after all liberated Polish prisoners condemned to death in the Soviet Union and had given them hope and the chance of a new life. Meeting him was a highly emotional experience for the soldiers. General Sikorski, in turn, was deeply impressed by the high morale of the army and their readiness to go along with him and his plans.

The visit gave the chaplains a good opportunity to talk to the general, who was very 
interested in the challenges of their work. The atmosphere of the meetings was warm and the exchange of opinions with the prime minister was very frank. Fr Cieński noted that General Sikorski was very unhappy about the apparently indifferent attitude of Pope Pius XII towards the German occupation of Poland. The Catholic Church, he suggested, was of no help to a nation in need. Poland might do better with the Polish National Church; ${ }^{40}$ he felt that the Poles would support this National Church. Fr Cieński thought this was a preposterous view, and opposed it; yet after a heated discussion General Sikorski still seemed to be convinced that the majority of Poles were for a National Church. ${ }^{41}$ Fr Cieński, who had been cut off for almost two years from the mainstream of Polish politics, was intrigued by Sikorski's views. He inquired everywhere, looking for an explanation, and uncovered a group of Polish politicians in London planning to use the church as a tool in realising their dreams for a better and stronger Poland. ${ }^{42}$ General Sikorski was probably attracted to their plans and reasoning.

This controversy did not, however, diminish Fr Cieński's high esteem for the prime minister and for his important role in the Soviet Union. The main fruits of his visit were the outcome of decisions by Stalin himself. Sikorski met Stalin in the presence of General Anders and Molotov, and the results were favourable to the Poles, although Molotov bitterly criticised the General Command and the chaplains of the Polish army. The official announcement on 4 December 1941 stated: that all imprisoned Poles were to be released; that the Polish army was to be increased to 100,000 ; that the army was to be transferred to the southern part of the country; and that a few thousand Polish soldiers would be sent to Great Britain for special training. Stalin also granted to General Sikorski a favour unique in a communist state: permission for Bishop Gawlina to visit the Polish army.

A feeling of unity with all Poles fighting for the freedom of Poland in Europe was the main result of General Sikorski's visit to Polish army camps in the Soviet Union. After years of humiliations the Poles could be proud of themselves and their nationality and could confidently tackle the tasks confronting them. The increase in the army to 100,000 , with the resultant change in the basis on which provisions were to be allocated, also promised an end to hunger. So far, the Soviet authorities had delivered sufficient food to the camps for only 26,000 people, although the number of Poles in the army camps had reached 44,000 . Nevertheless, the future looked promising.

\section{Moving South}

General Sikorski realised that in winter the army had no chance of performing regular training. Heavy snowfalls stopped trains and buses and made travel or marches impossible for months on end. Lack of proper drill and exercise made the units unfit for combat. The new agreement to transfer the army south was thus very welcome.

The new headquarters of the Polish army was in Yangiyul', not far from Tashkent, the capital of Uzbekistan, and 3,000 kilometres from Buzuluk. Evacuation of the army from the Buzuluk area started after Christmas. The first group left Buzuluk after 15 January 1942 with Colonel K. Rudnicki in charge.

About the end of January the Polish troops were unexpectedly visited by the NKVD dignitary General Zhukov. The general arrived with a proposal: Polish units should immediately be sent to the front to fight the Germans in those places where they were most urgently needed. The Poles were as yet unprepared for combat: they did not even have weapons, as these, though promised, had never been delivered. General Anders 
understood Zhukov's proposal as meaning that the Germans were to be used to destroy those Poles who had survived Soviet prisons and concentration camps, hunger and torture. ${ }^{43}$ His answer was that the Poles would fight, but together as an army, not as separate units, and only when their health had been restored, after they had been adequately nourished and had undergone a period of training for combat.

By the end of March, all the Polish units were in their new quarters. These were very widely dispersed, hundreds of kilometres apart in Kirgizia, Kazakhstan and Tajikistan. The placing of units over such large areas made efficient and systematic work extremely difficult for the chaplains. A considerable number of hospitals, schools and groups of civilians were added to their care, making their work even more onerous.

The hardships of travel over such a wide area were, however, balanced by mild weather. The first units left Buzuluk in temperatures of minus $50^{\circ} \mathrm{C}$. Yangiyul' welcomed them with warm spring. Arrayed in beautiful colours, everything seemed better: buildings, huts, trees, flowers, scenery. ${ }^{44}$

\section{Life in a Muslim Country}

At first the Poles experienced a feeling of isolation. After a few months in Buzuluk, they had won over the hearts of the local people, who had trusted them, supported them and frequented their chapels and halls. They had been respected for their spirit and their adherence to their Christian traditions, which the local people shared. The new camps, however, were in Muslim countries with a different and unknown culture and very few Christians. The Muslims, just like the Christians, were persecuted by men in uniforms representing an atheistic state. The Polish soldiers also wore uniforms, and this fact caused reserve and distrust. The local people simply refused to have anything to do with the newcomers; they would not sell them food or help them in any other way. Meanwhile they kept a close eye on everything the Poles did.

After a short time they began to notice that the Poles prayed regularly in their units and worshipped God. ${ }^{45}$ The chaplains held masses in trains, in halls and, when the weather was good, in gardens. During Lent and at Easter large congregations assembled in gardens for retreats, confessions, Lenten devotions, the Way of the Cross and adoration of Christ in his tomb. All this was observed and commented on favourably by local residents.

Together with three chaplains, Frs Cieński, Kantak and Kozlowski, the General Command organised retreats involving sermons, meditations and confession. Each chaplain led a retreat for a particular group: Fr Cieński for the women, Fr Kantak for the officers and Fr Kozlowski for the soldiers. The retreats for officers were well attended, but for some reason Fr Cieński's retreat for the women appears not to have been satisfactory.

Palm Sunday was celebrated in a very special way with a procession in a garden. Religious processions were regularly suppressed in the Soviet Union, and this was the first one the Poles had been able to hold. It was a true profession of faith. The Poles held green branches in their hands and walked proudly singing the praises of Christ the King. In the crowd there were Muslims too, also carrying green branches and praying. For them it was not only a religious event but also a spectacle. The 'Tomb of Christ' built in the garden and decorated beautifully with flowers impressed them deeply, as did the fact that not only women and children but also armed men came to pray at it. Easter Sunday Mass, with the procession of the Blessed Sacrament, the congregation singing about the Resurrected Christ and his almighty power over evil, was memorable 
for everyone present. After years of defeat and humiliation, the Poles felt in their hearts a power working through history and in their lives. The Muslims took part in the procession. They sensed the spiritual involvement of the Poles, and apparently found it very affecting. They noted that among the participants were members of the General Command, General Anders, and officers and soldiers from different units. Seeing a good number of Russian Orthodox and Muslims in the crowd, Fr Cieński asked them after the celebrations why they had joined the Catholics. Their answer was: 'You are faithful to God and we trust you. ${ }^{46}$ One thing, however, they found strange and inexplicable: the Polish affection for the army. To them, the army (the Soviet Army of course) was a despised organisation which should be avoided at all costs.

After some time, then, there was a change of attitude among the Muslims. The Poles were now admitted to shops and allowed to trade with the locals. Soon the Muslims confessed that for them atheists and Orthodox priests sent by Moscow were an object of mistrust, and at first they had suspected that the Poles were equally in the service of Moscow. Now they realised how mistaken they had been. The Poles were indeed different. The fear and reserve of the local population vanished. ${ }^{47}$

\section{A Dangerous Trap}

The prospect of a better climate for the ex-prisoners was welcomed by General Sikorski: they would be able to regain their lost health. 'They will be directed to the south of the country, where a better climate will make them feel better. ${ }^{38}$ However, it soon became apparent that the cold of the far north had been less dangerous for most of the Poles, in their weakened condition, than the mild weather of the south. ${ }^{49}$

A bad climate had been exchanged for one even worse and poor living conditions were replaced by plain squalor. During the winter months the temperature in the mountains reached 30 degrees below zero, whilst strong winds constantly blew in the valleys and persistent rain transformed the ground into an impassable quagmire. In spring the area was a breeding ground for malaria-carrying mosquitoes while in the summer the scorching sun burnt all the vegetation and made the rivers run dry. ${ }^{50}$

The Polish army was first hit by an epidemic of typhus, in May and June 1942 it was dysentery, and soon afterwards malaria followed.

That part of Uzbekistan where the Poles were billeted was treeless and the soil consisted for the most part of clay.

For several years the Soviet authorities laid a ban on the cultivation of rice there, for fear of malaria. But in 1942 the ban was lifted, and our camps were pitched along the edges of flooded rice-fields. The mosquitoes contaminated the army and the local population alike. ${ }^{51}$

Was this pure bad luck? Apparently not. According to Pobóg-Malinowski, the Soviet authorities hoped that adverse living conditions and epidemics would complete the designs of the Germans and liquidate the Poles. ${ }^{52}$

According to the figures printed by Ehrich, who had worked from the beginning as a Polish army doctor, when the organisation of the army was first undertaken, one man in three was affected with some form of contagious disease. At the height of the epidemic these figures had risen to one in two. ${ }^{53}$ 
Thousands fell ill with different complaints, but the field hospitals lacked medicines. ${ }^{54}$

The sad outcome was death on a large scale. At Yangiyul' and at Guzar in Uzbekistan people were dying like flies. Many young boys escaped from a preparatory army school in Vravsk, in the neighbourhood of Guzar, the reason being that 'everyone is dying there'. ${ }^{55}$ Digging graves was a soldier's main evening occupation. The huge number of deaths - on some days more than 120 - meant that funerals had to be very simple: two or three corpses without a coffin in one grave.

Sickness in all its forms and epidemics flourished to such an extent that it seemed very doubtful whether it would ever be possible to build up a fighting force of any kind so long as we remained on Soviet territory. ${ }^{56}$

Despite these difficulties, the General Command of the Polish army did its best to fulfil its basic goal which consisted of

\begin{abstract}
gathering into the units as many ex-soldiers and volunteers as possible. This was primarily in order to form a large and powerful force and secondly to save the lives of those who came from the northern areas of Russia where they undoubtedly would have perished.... Despite the opposition of the authorities and transportation difficulties, the rush of Poles into the ranks was such that by the middle of March the Polish Army had 70,000 soldiers as well as a number of families who encamped alongside the detachments. For all these people only 40,000 individual rations were provided, and on $6 \mathrm{March}$, a notice was received that even this quantity would be further reduced to $26,000.57$
\end{abstract}

\title{
Bishop Gawlina in the Soviet Union
}

The thousands of Poles exiled in the Soviet Union were constantly in the mind of Bishop Gawlina. On 6 September he sent Fr Król to Russia with seven crates of prayer and liturgical books, 30,000 crosses and some small field-altars to visit Polish units on his behalf. He was also to send him first-hand information about the status of the Poles there and prepare them for his coming visit. Bishop Gawlina was facing what was possibly the most important decision of his life. He finally decided that the shepherd's place is with his flock, and that he must go to Russia for good and serve the Polish Catholics there. Informed by Bishop Gawlina of this plan on 19 September, General Sikorski jokingly remarked that the bishop obviously preferred to be in charge of two and a half million people instead of the small Polish group in Great Britain. ${ }^{58} \mathrm{He}$ did not oppose his plans, though, and promised to support his transfer to the Soviet Union.

Soviet reality meant that Bishop Gawlina's plans could not be realised. A short visit was possible, however. On 26 October the entry visa to the USSR arrived, ${ }^{59}$ but for various reasons the visit had to be delayed for six months. The bishop used this time to collect and dispatch several new consignments of religious books and liturgical items to Russia.

On 28 April 1942 Bishop Gawlina finally arrived in Moscow. From the beginning his movements were carefully monitored by the Soviet authorities by means of microphones installed in hotel rooms, secret agents and provocateurs watching his reactions and trying to find him breaking Soviet law.

In a short time the bishop was able to see for himself what life for the Poles in Russia 
was really like. He was reduced to tears by a meeting with malnourished children being cared for in orphanages by the army: they looked like walking skeletons but sang 'From our hardships and miseries Poland will arise and live'. ${ }^{60}$ Every day the bishop had meetings with officers, soldiers, families of servicemen and children in schools and orphanages. The meetings usually started with solemn mass, a sermon and a service of confirmation, often given to several hundred adults and children at a time. The meetings were an occasion for festivity for the unit hosting the bishop, and for the local people, who regularly attended the religious services and other events, showing their respect to the 'Great Polish Mullah'. In Guzar, they sprinkled the dusty roads with water - a luxury in an arid country. In other places they offered local food, including fish, which was also a luxury in a country where people regularly went hungry.

The Poles decorated ruined buildings and set up altars there, and then staged cultural events. New Polish poems and songs were written, and boys and girls in national costumes danced Polish dances. The national costumes were often ingeniously made from paper, cardboard and the bark of trees. ${ }^{61}$ Polish dances were even adopted by the local people. On 17 July Bishop Gawlina saw Uzbek children dancing a Silesian 'Trojak'.

The bishop's diary has references to events which were of particular significance to him. On 24 June 1942 Colonel Klemens Rudnicki received the sacrament of confirmation together with his soldiers. On 18 July all members of one army unit, including their commander Captain Kiedacz and his officers, came to receive Holy Communion.

On 27 June General Wladysław Anders, a Protestant, was received into the Catholic Church. This move was prompted by his wish to be of one denomination with his soldiers, and also by his personal experiences in Soviet prisons, where he had witnessed the enormous spiritual support that the Catholic faith gave the Poles. He continued to support the work of chaplains of all denominations, but he was present at Catholic mass every Sunday and feast day. ${ }^{62}$

Concentration camps and prisons were slowly releasing more inmates. The bishop's visit provided an opportunity for more priests to be enlisted as army chaplains, including new young ordinands. In Yangiyul' he ordained three theological students recently released from prison: Zygmunt Dzierżek, Bolesław Jakimowicz and Antoni Jankowski. ${ }^{63}$ One memorable feature of this unusual ceremony was that liturgical vestments were available for the bishop and the new ordinands only: other priests had to wear civilian clothing. All the generals of the Polish army were present at the service.

During his visit the bishop was called on to assess complaints against certain priests. One was accused by his commanding officer of a complete lack of theological knowledge and heretical sermons. The bishop's inquiry into the case revealed that the 'priest' Galecki was indeed theologically untrained. The army court condemned him to three and a half years in prison for false pretences. ${ }^{64}$ At the bishop's request, however, the sentence was suspended. Another priest, Fr T. Wysoczyński, was removed from his post by the bishop for neglecting his duties. ${ }^{65}$

The bishop also felt responsible for the large civilian population imprisoned on collective farms and in concentration camps all over the country without any support or pastoral care. He proposed that several priests should stay with him permanently in the Soviet Union to serve those Poles unable to leave the country. He could not offer them a salary, or even personal freedom. They had to be prepared to work as labourers on collective farms or even to be imprisoned in concentration camps. On 24 June 1942 all priests present at a meeting with the bishop voted for this calling, should the bishop request it. Initially it was decided that 50 priests, with the bishop in charge, should 
form a hierarchical unit serving the Poles in Russia. ${ }^{66}$ Difficulties over recruiting able and mature priests meant that the number was soon limited to 20. Fr Cieński, Fr Chróściechowski and all the Jesuits were ready to offer their services to the bishop. ${ }^{67}$ As a result of these moves there were 54 Polish priests in the Soviet Union: 39 in the army and 15 visiting Polish civilian communities. ${ }^{68} \mathrm{~A}$ further 50 priests were still in prisons.

The bishop was sincerely committed to transferring himself permanently to the Soviet Union. His plan was, however, firmly rejected by General Zhukov. Priests performing their religious duties among civilians would be arrested and imprisoned: such was Soviet law. Thus the priests had to stay in the Polish army, only occasionally helping civilians as circumstances permitted. This was as much as they could hope to do.

Bishop Gawlina was instructed by General Sikorski to inquire into morality in the army, which had been represented to the general as unsatisfactory. The bishop heard that complaints mainly concerned sexual abuses, theft and drunkenness in some units. There were also strong complaints about the poor moral standards in certain detachments of the Auxiliary Women's Corps. Some offenders were expelled from the army; but the bishop's overall conclusion was that moral standards in the army were generally very high and that the soldiers had a positive attitude to the correction of shortcomings.

The bishop had arranged for a first consignment of Bibles, prayer books and other religious books, printed in London, to be sent to the Soviet Union on 9 August 1941. As already noted, crosses, field-altars, prayer books and other religious literature were dispatched with Fr Król on 6 September, and another consignment was sent during the six months before the bishop left for Moscow. The bishop received the goods while visiting troops in Russia; but some of the deliveries were stopped by the Soviet authorities. On 15 May, a Maly modlitewnik (small prayer book) printed by the Catholic Truth Society in London and a small picture of Our Lady of Częstochowa with text in Russian were confiscated. On 29 May eight crates of prayer books were impounded in Murmansk. A similar fate awaited a consignment of prayer books and other religious items in Kuibyshev. On 1 July 1942 a small picture of St Andrew Bobola, patron saint of Eastern Poland and of those who had converted to the Catholic faith from the Orthodox Church, served as the pretext for a diplomatic row, and thereafter all religious items and literature arriving in the Soviet Union were confiscated.

While visiting army units, Bishop Gawlina was on many occasions in touch with Polish and Russian Jews. There were Polish Jews serving in the army, and Russian Jews would quite often apply to join as a method of leaving the Soviet Union. Recruitment offices were, however, closely watched or even staffed by NKVD members, who surveyed all applications and demanded rejection of Jewish ones. The Soviet authorities would later explain to these Jews that their rejection was due to Polish antisemitism. The Poles were unable to change this situation, although General Anders protested to Stalin, on the grounds that the Poles and the Polish authorities were under no obligation to observe Russian law as in the army the Polish Constitution held sway, and thus granted the right of Polish citizenship to all minorities. Meanwhile, the Poles did what they could. Wherever it was safe and possible to do so, they admitted Jews to the army; wherever the NKVD was keeping a close watch they had to reject the applications. This explains the complaints from Polish Jews that they had been rejected by the Polish army in Russia, as well as the fact that at the same time Jews were serving in that army. 
Bishop Gawlina was frequently visited by civilian Jews and rabbis, who usually wanted him to help themselves and their families to leave the Soviet Union. On 2 August 1942 the bishop succeeded in getting Rabbis Landau and Hager and their families out of the Soviet Union, and he was also involved in an argument with the Soviet authorities, who were refusing children from a Jewish orphanage the right to leave Russia on 8 August 1942 as planned. As a result of the bishop's intervention these children joined children from a Polish orphanage and left Russia with them.

In August 1941 the hostility of the official attitude of the Soviet authorities to all religious activities softened somewhat, and this fact was reflected in official talks between General Panfilov and General Anders. At that time persecution of the Orthodox Church virtually ceased for the sake of uniting the nation in the face of the German onslaught. This new attitude to religion was a clever manoeuvre for propaganda purposes, misleading many western journalists and politicians. Fr Kaczyński, a well-known Polish Catholic priest and politician, praised the Soviet government for granting religious freedom to all in the country. ${ }^{69}$ The desperate need for national unity and support from the West became less pressing after 11 June 1942, however; this was the day on which the Soviet-British treaty was signed and promises of massive western assistance were made. The more liberal policy towards religion was reversed and repressive legislation and persecution swiftly returned. The Polish priests were closely monitored by the NKVD in their work among civilians, and some were arrested.

Bishop Gawlina devoted all his time to the Poles, whom he considered to be in his pastoral care. After four weeks in the Polish Embassy in Kuibyshev, where he organised pastoral work in the army units and in civilian communities, he left Kuibyshev to visit these places personally. Between 6 June and 19 July he made an extensive tour of Polish settlements in Kazakhstan, Uzbekistan and Kirgizia. He was probably the first Catholic bishop to work in the heart of Central Asia. Apart from pastoral duties he was involved in charitable activities and in organising supplies of religious books, crosses and rosaries. The bishop was under constant surveillance as he made his visits, and the authorities voiced their disapproval of his effectiveness: 'The consequences of two months of your work here will take the next twenty years to rectify. ${ }^{70}$ Back in Yangiyul', he spent several weeks trying to organise a permanent pastoral structure for the civilians who would be remaining in Russia after the eventual evacuation of the Polish army. All these plans were strongly opposed by General Zhukov, who demanded that all Catholic priests should leave the Soviet Union with the army.

The visit of Bishop Gawlina came at a crucial time for the Polish army in the Soviet Union. A new type of soldier was being formed in war conditions and hostile territory, after a long term of demoralising imprisonment. On the strength of his office and high moral authority, the bishop imposed strict rules on the work of the chaplains, investigated and corrected abuses in work and conduct and praised good work and commitment. His personality and attractive vision of the world also influenced both officers and soldiers. He was most impressive and non-controversial both at the altar and in the pulpit. His contacts with civilians and non-Catholics were friendly and sympathetic. Discussions and exchanges of view won him many supporters. Generally speaking he was of great help to the Poles at a time of considerable crisis.

\section{Poles and Jews in the Soviet Union}

In attempting to describe Polish-Jewish contacts in the Soviet Union one must beware of generalisations. The Polish Jews in Russia were far from uniform. They differed 
among themselves in their attitudes to many aspects of their life - religion, culture and politics. The problem of survival of a nation which had for thousands of years been dispersed throughout the world contributed to the formation in the Jews of a mentality of distrust together with a capacity for collaboration, for the sake of survival, with those who in fact threatened their existence. 'The group marked for complete annihilation,' comments one reseacher, 'was caught in the straitjacket of four-millenia-old history that always reacted to force with alleviations and compliance.' The reason for this, he argues, may be 'that Jewish experience harbours a deep seated unwillingness, ultimately, to credit the existence of evil. ${ }^{71}$

It was, then, perhaps inevitable that from time to time tension should arise between Jews and Poles in the Soviet Union. According to a report from Ambassador Kot, ${ }^{72}$ Poles were resentful of the fact that Jews welcomed the Soviet army of occupation in 1939. They accused Jews of collaboration with the occupying forces and of spying on Polish citizens and denouncing them to the NKVD. In the Polish army, some Jews were suspected of being in the service of the NKVD. These were mostly Jews from the eastern territories of Poland and those of lowly social origin who before the war had lived in enclosed Jewish communities centred on the synagogue and Jewish school and who had had little contact with the everyday life of their Polish neighbours. By contrast, the Jewish intelligentsia was generally much more integrated into Polish cultural and social life. Most of its members considered themselves to be Poles and presented themselves as such throughout the years when certain countries were hostile to Poland. The news about the amnesty for imprisoned Poles was welcomed with joy by these Jews as a real achievement for Poland.

The new Polish army in the Soviet Union was, as we have seen, a place of refuge for a great number of Jews. Certainly there were tensions between Polish and Jewish soldiers for a variety of reasons. General Anders rejected the idea of special Jewish units which could later have been used to further the Jewish cause in Palestine. Nevertheless, he strongly protested against all anti-Jewish attitudes in the army. It seems that the tensions were based on political and moral issues rather than on religious grounds. In prison, religious Jews and Poles respected each other and mutually facilitated religious practices.

The Polish Embassy employed Polish Jews - 82 out of a staff of 387 . They were also selected to represent the Polish Government in Exile in many offices of Polish delegations in the Soviet Union. ${ }^{73}$

In the most difficult of circumstances, the Poles evacuated from the Soviet Union about 4,000 Jews - soldiers, their families, children, orphans and a number of rabbis not included in the Polish army. In the opinion of the British authorities the Poles did their best to evacuate as many Jews as possible from the Soviet Union. ${ }^{74}$

\section{Time of Departure}

The Soviet authorities gave a long list of guarantees which were to enable the formation of a Polish army on Soviet soil: but they were never fulfilled, and this made the task utterly impossible. ${ }^{75}$ The main problem, however, was not a military one: it was the basic question of food supplies. By the middle of March 1942, the 70,000 Polish soldiers, with some of their families camping close to them, were surviving on 40,000 individual rations. These were further reduced to $26,000 .{ }^{76}$ General Anders reacted swiftly to the reduction. His subsequent visit to Stalin on 18 March 1942 resulted in a decision for partial evacuation of the Polish army from Russia.

The Poles had become an uncomfortable problem for the Soviet authorities. One 
immediate problem was that they were demanding clarification concerning prisoners from Katyn', Starobel'sk and Ostashkov. More generally, however, the Soviet authorities understood that in the Polish army they had a community which was resistant to communism and immune to their propaganda, and which therefore represented a potential danger to the entire system. Plans to have the Polish army destroyed by the Germans by sending it inadequately prepared and armed to the front had come to nothing. The epidemic in Turkestan had also failed to eliminate it. A renewed imprisonment of 100,000 Poles would very likely poison the Soviet Union's international relations. One solution remained: to get them out of the country. ${ }^{77}$

The first evacuation to Persia started on 24 March 1942 and was completed on 3 April. The evacuees comprised 33,069 soldiers with 10,789 civilians and 3,100 children. ${ }^{78}$ The agreement between Britain, Poland and the Soviet Union and the successful Tashkent conference on 31 July 1942 opened the way to a second evacuation. This time about 25,000 people, families of serving soldiers, left the Soviet Union. Families of Polish citizens who were not of Polish nationality could also be evacuated.

This mainly affected Jews for whom General Anders made special efforts.... Up to the last moment the greatest difficulty proved to be the question of the national minorities, as the Soviets did not want to let them go, whilst the Poles tried to make it easy for them to leave. The Soviets even began to spread rumours that, as anti-Semites, the Poles did not want to take Jews. It was necessary to correct these rumours continuously. On the whole, however, the transports left regularly and the figure of 70,000, including 4,000 Jews, was nearly reached. ${ }^{79}$

The second evacuation started on 9 August and was completed on 1 September 1942. The evacuees were so ill and emaciated that 568 died soon after their arrival in Pahlevi. $^{80}$

These large-scale evacuations overshadow the 'small' evacuation of Polish children from Buzuluk to India at the beginning of 1942. In January of that year, the Polish Embassy in Moscow was informed that the Indian government would admit to India 500 Polish orphans from the Soviet Union. ${ }^{81}$ These children, accompanied by qualified staff and a chaplain, left for Bombay at the end of the month. The first chaplain delegated to the Polish orphanage in Bombay was Fr F. Pluta. ${ }^{82}$

Bishop Gawlina left the Soviet Union for Persia on 1 September 1942 with the last Polish evacuees.

\section{Epilogue}

The exodus to Persia did not signal the end of the Polish odyssey. Palestine, the Lebanon, Egypt, Italy and battles throughout Europe still awaited them. The Polish army was a quarter of a million strong. For the soldiers, the suffering and conflict would have had some justification if the future had included the freedom of Poland. However, the end of the war and the Yalta agreement destroyed hopes of a free Poland and deprived the Polish sacrifices of meaning. The Polish army came close to despair and rebellion. The Poles maintained that they had kept faithfully to all the pledges they had given to the Allies, and that it was the Allies who had betrayed them.

The Poles settled in Great Britain, the United States, Canada, Australia and other countries. A high proportion of them felt bitter and abandoned. Their priests went with them to all parts of the globe. Their work and help were still needed. 


\section{Notes and References}

1 Julian Siedlecki, Losy Polaków z ZSSR w latach 1939-1986 (London, 1987), pp. 33-40.

2 Quoted by Norman Davies, God's Playground: a History of Poland (Oxford, 1981), vol. 2, pp. 447-8.

3 Polskie Sily Zbrojne w Drugiej Wojnie Światowej (London, 1950), vol. 3, p. 33.

4 Zbigniew S. Siemaszko, W Sowieckim Osaczeniu (London, 1991), pp. 10-12.

5 Siedlecki, op. cit., p. 40; Praca Zbiorowa, Napaść Sowiecka (London, 1985), p. 101.

${ }^{6}$ Keith Sword, The Soviet Takeover of the Polish Eastern Provinces, 1939-4I (London, 1991), p. 45; Siedlecki, op. cit., p. 40.

7 ibid., pp. 40, 45, 46.

8 Davies, op. cit., vol. 2, pp. 448-9.

9 Siedlecki, op. cit., p. 46.

10 Davies, op. cit., vol. 2, p. 451-3.

11 Mrs Todzia Welz, statement to the author.

12 Wiesław Jan Wysocki, Bóg na nieludzkiej ziemi (Warsaw, 1982), p. 111.

13 ibid., p. 48.

14 ibid., p. 59.

15 O. W. Cieński, Z dziejów polskiego duszpasterstwa wojskowego (Rome, 1985), p. 295.

16 ibid., p. 321.

17 ibid., pp. 300, 303, 306, 307, 313, 314, 316.

18 ibid., pp. 294, 295.

19 Anatol Krakowiecki, Ksig̨żka o Kolymie (London, 1950), pp. 78-81.

20 Wladyslaw Anders, Bez ostatniego rozdzialu (Newtown, 1949), p. 81.

21 Cieński, op. cit., p. 323.

22 ibid., P. 332.

23 ibid., p. 326.

24 ibid., p. 513.

25 Anders, op. cit., p. 84.

26 Siedlecki, op. cit., p. 99.

27 Cieński, op. cit., p. 330.

28 Anders, op. cit., p. 85.

29 Siedlecki, op. cit., p. 83.

30 ibid., p. 84.

31 Cieński, op. cit., p. 514.

32 Anders, op. cit., p. 85.

33 Cieński, op. cit., p. 517.

34 ibid., p. 517.

35 ibid., p. 520.

36 Maria Maćkowska, Pomocnicza Slużba Kobiet w Polskich Silach Zbrojnych (London, 1990), p. 12.

37 Tadeusz Wyrwa, 'Biskup Gawlina, General Sikorski i Watykan', Zeszyty Historyczne (Paris), no. 90 (1989), p. 102.

38 Ks. Zdzisław Peszkowski, Wspomnienia jeńca z Kozielska (Warsaw, 1989), pp. 119-22.

39 Cieński, op. cit., p. 534.

40 ibid., p. 537.

41 The Polish National Catholic Church of America is an Old Catholic church that arose in the late nineteenth and early twentieth centuries among Polish immigrants in the USA who left the Roman Catholic Church. Polish immigrants were unhappy with the Roman Catholic Church in the USA for several reasons, including various internal disputes and dissatisfaction with pastors, the fact that there was no bishop of Polish birth or descent in the American hierarchy and an 1884 ruling that gave bishops the title to all diocesan properties.

42 Cieński, op. cit., p. 537.

43 Anders, op. cit., p. 132; W. Pobóg-Malinowski, Najnowsza Historia Polityczna Polski (London, 1986), 2/III, pp. 225, 226. 
Cieński, op. cit., p. 728.

45 ibid., pp. 734-5 (Fr Cieński's testimony).

46 ibid., p. 735.

47 ibid., p. 126.

48 Pobóg-Malinowski, op. cit., p. 209.

49 Józef Czapski, The Inhuman Land (London, 1987), p. 149.

50 Józef Garliński, Poland in the Second World War (London, 1985), p. 149.

51 Czapski, op. cit., p. 239.

52 Pobóg-Malinowski, op. cit., p. 228.

53 Czapski, op. cit p. 239.

54 Garliński, op. cit., p. 149.

55 Czapski, op. cit. (Polish edition), pp. 189-90.

56 ibid., p. 236.

57 Garliński, op. cit. p. 150.

58 Wspomnienia Ks. Biskupa Józefa Gawliny (unpublished), p. 286.

59 ibid., p. 288.

60 ibid., p. 308.

61 ibid., p. 310.

62 ibid., p. 307.

63 Dziennik Ks. Bp J. Gawliny (unpublished), p. 317.

${ }^{64}$ Siemaszko, op. cit., p. 286.

65 Dziennik Ks. Bp J. Gawliny, p. 21.

66 Wspomnienia Ks. Bp J. Gawliny, p. 319.

67 loc. cit.

68 Siemaszko, op. cit., p. 283.

69 Wspomnienia Ks. Bp J. Gawliny, p. 6.

70 ibid., p. 313.

71 Monty Noam Penkower, The Jews Were Expendable (Chicago, 1983), p. 289.

72 Polskie Sily Zbrojne w Drugiej Wojnie Światowej (London, 1975), vol. 2, pp. 252-3.

73 Richard C. Lukas, 'Polacy i Zydzi', Znaki Czasu (Rome), no. 17 (1990), p. 246.

74 ibid., p. 245.

75 Garliński, op. cit., pp. 152-3.

76 ibid., p. 150.

77 Pobóg-Malinowski, op. cit. p. 237.

78 Bohdan Wroński, 'Wysilek mobilizacyjno-organizacyjny Polskich Sil Zbrojnych na Zachodzie w Drugiej Wojnie Światowej', Rzeczpospolita Polska, no. 11 (356), p. 5.

79 Garliński, op. cit., p. 155.

80 Wroński, op. cit., p. 5.

81 Jan Kwapiński, 1935-1945 (z pamiętnika) (London, 1947), p. 57.

${ }^{82}$ Cieński, op. cit., pp. 540-1. 